\title{
A SOCIOLOGIA DO DEKASSEGUI \\ Estudos Sociológicos da Imigração Japonesa ${ }^{1}$
}

Toyoie Kitagawa

RESUMO: O presente trabalho enfoca os aspectos sociológicos e históricos da imigração japonesa, remontando ao isolacionismo do período Tokugawa e discute o fenômeno dekassegui, que teve início em 1964 e continua até os dias de hoje.

ABSTRACT: The present article has its focus in sociological and historical aspects of Japanese immigration, remounting to Tokugawa pericd isolationism and discusses the phenomenom named dekasegi which started in 1964 and continues until today.

PALAVRAS-CHAVE: dekassegui; imigração japonesa; isolacionismo; período Tokugawa; estudo sociológico.

KEYWORDS: dekasegi; Japanese immigration; isolationism; Tokugawa period; sociological study.

Meu nome é Toyoie Kitagawa e o Kitagawa significa o "rio onde corre muita alegria" e o nome Toyoie, o "rico universo", cuja interpretação pode ser "pensar, dentro do planeta Terra, que é um espaço limitado, na riqueza do universo sem limites" Acho até que isso mostra uma postura voltada para o futuro. Tenho inclusive a impressão de

1. A presente palestra foi proferida em 28 de novembro e 6 de dezembro de 1997, na sede da Fundação Japão e Casa de Cultura Japonesa, respectivamente, sob a promoção conjunta da Fundação Japão e Centro de Estudos Japoneses da USP.

2. Toyoie Kitagawa é professor da Toyo University (Tóquio) e foi diretor da Sociedade Japonesa para Promoção da Ciência de abril de 1997 a março de 1998. 
que comecei a me debruçar em estudos que desenvolvo agora devido ao espírito impregnado nessas letras que constituem meu nome mas, quando criança, sempre perguntavam a leitura desses ideogramas, e como isso me incomodava, eu tinha ódio do meu pai. Quando comecei a entender o significado do meu nome, meu pai já não era vivo.

Muito bem, entrando no tema de hoje, a emigração surge pela primeira vez na história do Japão em 1868 , ano $1^{2}$ do período Meiji, com os 53 emigrantes partindo para o Havaí. Iniciava-se a emigração coletiva. Em 1883 (ano 16 de Meiji), 36 pescadores de pérolas se dirigiram para a Austrália como emigrantes oficialmente aceitos pelo governo. A partir de 1885 (ano 18 de Meiji), a emigração para o Havaí passou a fazer parte formalmente do acordo entre os dois países. Para a América Latina, em 1897 (ano 30 de Meiji), dirigiram-se 35 emigrantes ao México, buscando construir uma colônia como idealizava Enomoto Buyô, e em 1899 (ano 32 de Meiji), 700 emigrantes aportaram no Peru.

A migração japonesa tem suas raízes na história social do sakoku, "isolacionismo", de antes da abertura dos portos. A emigração tem de ser pensada juntamente com a abertura do país na ocasião da Restauração Meiji. Se tivesse sido Oda Nobunaga o unificador do Japão, sob um forte sistema absolutista, os japoneses teriam saído muito mais para o exterior e poderia existir agora vários lugares onde se fale o idioma japonês.

O que foi o sakoku, o isolacionismo do Japão? Ele consistia no sistema que tinha como princípio fazer o registro civil dentro da unidade de vila, atestando, em nome da responsabilidade coletiva da vila, não haver nenhum cristão, e onde se documentava o nome, a idade, o sexo, a renda, o número de cavalos etc. de cada um dos membros da família. Exercia o papel de registro civil e registro para o pagamento de impostos.

Além disso, fato importante foi a manutenção do número de famílias e da população durante os 300 anos do período de isolamento do país. Existia somente um número fixo de famílias e de população para manter a força de produção alimentícia de uma vila. Ainda, na pesquisa dos 300 anos do período Edo, que realizei na Vila Yoshikawa da província de Yamagata, sempre o número da população masculina superava o da população feminina.

Tendo como centro a população masculina que se sobressaía nos trabalhos braçais, a população feminina existia na faixa mínima para gerar e criar os filhos, em função da manutenção da taxa populacional. Para tanto, realizava-se o mabiki, a prática de exclusão dos filhos de acordo com o sexo. Após verificarem o sexo da criança, optava-se por sua vida ou por sua morte. Era uma realidade cruel. Os bonecos de madeira chamados de kokeshi, cuja etimologia é ko-o kesu "eliminar a criança", eram feitos para velar o espírito de crianças que não puderam viver. Na vila Yoshikawa, dizem as lendas que as grávidas se sentavam dentro do rio gelado para provocarem aborto.

No Japão antes da Restauração Meiji, havia muitos homens que nunca se casavam, e que passavam a vida toda como hiyameshi-gui "comedor de arroz frio" (como alusão ao tratamento não privilegiado como o do primogênito). Sem poderem gerar seus filhos, passavam a vida toda como solteiros, dentro da família cuja figura central era o primogênito, sendo apenas mais uma força de trabalho doméstico. 
Há também os chamados naki-kozô, ou seja, "meninos chorões" Quando uma menina nasce e não vem em seguida nenhum filho varão, havia um costume de se fazer suceder a família, casando a filha mais velha com um homem que aceitasse permanecer nessa casa. Esse sistema de sucessão era chamado de ane-katoku-sôzoku. Nesses casos, o menino que porventura nascesse bem depois da irmã mais velha era mandado para as lojas como aprendiz de trabalho e era chamado de "menino chorão". Antes de o menino tornar-se independente, os pais já teriam envelhecido e, portanto, preferiam casar a filha mais velha com alguém que tivesse já força de trabalho. Como esse genro tomava a sucessão familiar, o filho varão tinha de sair de casa.

Em lugares onde o campo a ser herdado era pequeno, havia um outro sistema de sucessão chamado basshi-sôzoku, que consistia no abandono da casa pelos filhos, à medida que se emancipavam. Quando chegava a hora de o caçula tornar-se independente, os pais se aposentavam e esse caçula passava a cuidar deles. Como havia limite no número de pessoas que a família podia sustentar, os filhos seguiam o seu caminho um depois do outro.

Há outras histórias que transmitem realidades dolorosas. Os missionários cristãos, chegando ao Japão nos tempos de guerras internas (século XVI), enviavam à Europa cartas que hoje em dia são chamadas de Kirishitan Monjo, Documentos Cristãos e, segundo essas cartas, os japoneses eram, entre os asiáticos, um povo extremamente trabalhador e inteligente, mas praticava um ato bárbaro, difícil de se entender, como diz o seguinte trecho: "Numa manhã, quando fui à beira da praia, encontrei uma mãe lançando ao mar uma criança recém-nascida". Dessa maneira, no arquipélago japonês, praticavase o controle do crescimento populacional. Sabe-se que nos registros civis das vilas da época constatavam números populacionais de acordo com classe e faixa etária totalmente irregulares, comprovando o controle artificial do aumento da população. É possível constatar a redução e o aumento populacional pouco naturais, de acordo com o lema: "diminuir quando se aumenta, aumentar quando se diminui demais"

Falarei agora das constatações referentes aos homens que passaram a vida inteira como solteiros, chamados de hiyameshi-gui "comedor de arroz frio", constituindo força de trabalho doméstico, dentro da família cujo centro era o primogênito (o irmão mais velho). Há uma vila, denominada Shirakawa, com grandes famílias morando em construções chamadas de Gasshô-zukuri (construções que lembram as duas palmas da mão com as pontas juntas). Os historiadores da linha evolucionista de Spencer defendem a tese de que a estrutura social dessa vila teria sido nada menos que o resquício da família antiga, anterior à evolução. Foi o meu mestre Koyama Takashi quem se opôs a essa teoria. Ele verificou com minúcia os registros das grandes famílias e constatou que, na verdade, elas não eram fósseis de famílias com estrutura de épocas antigas mas que, nessa sociedade, apenas o primogênito se casava para garantir a continuidade da família, e os demais filhos permaneciam solteiros, submetidos a condições desumanas, como força de trabalho doméstico necessária para a criação de bichos de seda.

As grandes casas de Gasshô-zukuri constituíam um espaço com uma grande sala para a criação de bichos de seda e para a convivência dos segundo e terceiro filhos. $O$ prof. Koyama também esclareceu que os segundos e os terceiros filhos que passavam a 
vida toda solteiros deixavam um contingente de filhos bastardos. As pessoas de hoje tendem a associar uma imagem bucólica e harmoniosa à estrutura familiar anterior ao período moderno mas, na realidade, era um local de trabalho familiar em condições bastante adversas.

A expressão japonesa yome-shûto, "nora e sogra", reflete muito bem os problemas familiares. A nora é bastante maltratada pela sogra, mas vive o tempo todo suportando o mau trato porque logo a sogra morrerá e ela própria poderá vir a ser sogra, assumindo o poder (o que é chamado de "poder da concha de arroz"). A paciência lhe garante a aquisição futura do poder.

Em outras palavras, essa sociedade tem uma estrutura bastante simples: como há um número fixo de população dentro de um determinado espaço, sem lugar para uma população excedente, uma simples espera garante o seu poder. Portanto, a entrada de alguém de fora que perturbe a sucessão dessa ordem é totalmente rejeitada. Mesmo quando a nora seja uma Oshin ${ }^{3}$, ela suportava os maus tratos da sogra, esperando a sua vez de ser também a velha cruel.

Assim, o isolacionismo significava uma forma de um número determinado de pessoas viverem dentro de um espaço limitado. A população excedente constituía um perigo que punha em risco a sobrevivência dos outros, tornando-se então alvo de exclusão. Não se constata no período do isolacionismo casos de uma mesma mulher ter tido e criado mais de 10 filhos. As mães japonesas com prole numerosa fazem parte do novo fenômeno de pós-Meiji.

O controle de natalidade era praticado também no Ocidente, mas se fazia através do estímulo à preservação da virgindade e do casamento tardio. Se guardassem a virgindade e se casassem tardiamente, a porcentagem de gravidez permaneceria baixa. A proibição da contracepção e do aborto eram e continuam sendo, para os católicos, questões básicas de ética familiar até hoje. No Japão, era comum a prática de yobai (visitas do homem à casa da mulher, à noite) e era rara a preservação da virgindade. Os católicos que não evitavam a gravidez possuíam, pois, uma cultura distinta, na própria base, da sociedade japonesa onde eram admitidos o aborto e a exclusão dos recémnascidos.

Podemos ver, assim, que as estruturas sociais peculiares de ie ("casa") e do mura ("vila") dos japoneses foram consolidadas no período do isolacionismo. Percebe-se claramente que essa política peculiar do Japão, preparada para impedir a invasão e a intromissão dos países estrangeiros e, de outro, para manter o poder dos Tokugawa, constitui a base do sistema social e da cultura do Japão, considerada nihonteki, ou seja, "própria do japonês". O mecanismo social de não se aceitar facilmente os estrangeiros, e mesmo os descendentes de japoneses, criando uma barreira de separação, é o resquício da sociedade e cultura japonesa dos tempos do isolacionismo do país. O princípio social do Japão dessa época era uma sociedade de sucessão que garantisse a vida de um determinado número de pessoas dentro de um determinado espaço. Uma sociedade de população controlada é uma sociedade que "espera a sua vez". É essencialmente diferente

3. Oshin é nome da personagem feminina que protagonizou a novela com o mesmo título, e passou a simbolizar a pessoa que sofre os maus tratos da sogra, suportando-os com resignação. (N. da T.) 
dos princípios sociais da sociedade de imigrantes onde a renda e a posição são garantidas mediante a capacidade e os feitos de cada um.

A abertura do país, deixando de lado o isolacionismo, significava então cessar o controle populacional e aumentar o número de japoneses que falassem a língua japonesa. É a constituição do Estado Étnico Moderno. A população excedente ia às grandes cidades e era absorvida como operários de fábricas ou como soldados. Isso constituiu a base da política de "país forte, soldados fortes" e a política de "aumento da produção industrial" O primogênito, que é o chefe da família, preserva a casa e a vila, e os segundo e terceiro filhos vão à cidade, ou já desde o ano $1^{\varrho}$ de Meiji, começam a sair para o exterior como dekassegui.

No período Meiji, houve pessoas com visão voltada para o futuro como Enomoto Buyô, que achavam que deveriam enviar ao mundo os seus emigrantes. Ocupando um alto cargo do Ministério da Marinha do Xogunato, ele viajou com o navio militar Kaiyômaru, encomendado à Holanda, e na volta ao Japão passou pelo Rio de Janeiro, em janeiro de 1867 . O primeiro japonês a pisar o solo brasileiro foi um pescador náufrago, salvo por um barco russo, que ia ao Japão via América do Sul e aportou em Florianópolis, em 1803. Vinte anos depois, em 1824, os imigrantes alemães chegavam ao Rio Grande do Sul como colonos. No Rio Grande do Sul, 25 de julho é considerado o dia da Imigração Alemã.

No próximo ano, a imigração japonesa comemora os seus 90 anos, e a imigração alemã, os seus 175 anos. A colonização alemã em Blumenau, atualmente uma cidade que lembra muito as cidades alemãs, comemora os seus 150 anos no ano que vem.

A personalidade que influiu na administração emigrantista do governo japonês na fase inicial foi Enomoto Buyô. Ele estava a serviço do Xogunato e, na guerra da Restauração, encerrou-se no Goryôkaku para resistir à tropa militar, mas posteriormente sua capacidade foi reconhecida e passou a trabalhar para o governo de Meiji. Quando ministro das Relações Exteriores, em 1891 (ano 24 do período Meiji), instituiu o Departamento de Emigração. O nome dekassegui em katakana aparece pela primeira vez a nível oficial, e considero que a origem do nome usado hoje se encontre aqui.

Em 1893 (ano 26 de Meiji), Enomoto Buyô, após renunciar ao ministério, reuniu as pessoas influentes e instituiu a Sociedade para a Promoção da Imigração, idealizou uma colônia e exortou os emigrantes. Entre os membros, estavam personalidades importantes como Komura Jutarô, Konoe Atsumaro, Hoshi Tôru, Kaneko Kentarô, Nemoto Shô. Mas os locais idealizados para a emigração, no início, eram a América do Norte e o México. Foi em 1908 que os primeiros imigrantes chegaram ao Brasil, 41 anos depois de Enomoto ter passado no Rio com o barco militar do Xogunato.

Mudando um pouco de assunto, eu trabalho como diretor da JSPS num prédio cujo administrador, o sr. Pedro, contou-me que seus antepassados vieram de Nápoles, Itália, para trabalhar como dekassegui ao Brasil que enfrentava a falta de mão-de-obra braçal após a libertação dos escravos, em 1888. Mais tarde, voltaram à Itália, e seu avô voltou novamente como imigrante. Fala-se muito de imigrantes japoneses que voltam ao país de origem como dekassegui, mas sabe-se que tal retorno já acontecia com os italianos. 
Foi em 1874 que os primeiros italianos entraram no Estado de São Paulo, portanto, os antepassados do sr. Pedro foram os primeiros imigrantes italianos. Ele é uma pessoa bem-sucedida, com formação superior, e sua esposa é administradora de uma firma famosa de doces. Ele tem um porte altivo e fala fluentemente o italiano e o inglês. E seu amor à Itália se manifesta em suas palavras.

O proprietário desse prédio, chamado Nicolau, também é um descendente de imigrantes italianos, possui grandes propriedades em Rio Claro e é presidente do conglomerado Scarpa. Em 1875, a ferrovia Paulista estava concluída até Rio Claro e ele descende dos imigrantes que foram a Rio Claro. Sua esposa, sra. Assíria, é descendente de italianos que formam um conglomerado na Argentina, o que nos comprova de perto a existência de poderosas famílias de descendentes italianos que atuam entre o Brasil e a Argentina.

O sr. Pedro é como um gerente que presta serviços à família Scarpa. Seu escritório se encontra um andar abaixo do meu e sempre conversamos. Quando falávamos dos imigrantes italianos, veio à baila a obra História do Meu Coração, de Amicis. Na Itália, a história é popularmente conhecida com o título Minha Mãe mas, no Japão, por Três Mil Milhas em Busca da Mãe. É uma obra famosa no Japão por ensinar aos jovens e crianças o que é a paciência e a coragem. Mas, o interessante é que o sr. Pedro considera essa obra como sendo sobre imigrantes italianos e dekassegui.

Segundo a obra, à mesma época em que Enomoto, anteriormente citado, criava a Associação para a Promoção da Emigração, uma mãe deixava o marido e os filhos em Gênova e ia de dekassegui à Argentina. Marco, de 13 anos, viaja em busca da mãe, cruzando o oceano Atlântico e desafiando múltiplas dificuldades. $O$ menino sofre um assalto dentro do navio mas, se olharmos sob outro ponto de vista, pode-se dizer que entre a Itália e a Argentina havia uma rota fixa de emigrantes e de dekassegui a ponto de o garoto ter conseguido fazer sozinho uma viagem marítima de $12.000 \mathrm{~km}$.

Em 1894, sob a ordem de Enomoto, Nemoto Shô - um entusiasta que fazia campanha a favor da emigração - fez uma visita a São Paulo como secretário do Ministério da Agricultura e Comércio e escreveu em seu relatório a Enomoto que: "Para o empreendimento da emigração japonesa, São Paulo é bastante promissor..." Contava também sobre a chegada incessante dos imigrantes italianos: "Muitas centenas chegam da Itália por semana, é uma leva atrás da outra..." Em 1886, a história Três Mil Milhas em Busca da Mãe já era um best-seller no Japão, e o relatório do Nemoto Shô comprova o fato narrado na obra.

Quando Enomoto Buyô aportou no Rio, a imigração italiana na América do Sul se iniciava, e quando Nemoto Shô chegou a São Paulo, a base da vida dos imigrantes italianos já estava consolidada no Brasil e na Argentina.

No dia 18 de junho do ano próximo, comemoram-se os 90 anos da chegada do navio Kasatomaru no dique $\mathrm{n}^{\mathrm{1}} 14$ do porto de Santos com 781 imigrantes, mas a imigração italiana comemora os 125 anos após a chegada a São Paulo. São apenas 35 anos de distância mas que marcam a grande diferença entre o início da imigração japonesa e a fase mais avançada da imigração italiana, resultando na configuração de patrão italiano e colono japonês. Comparada com a imigração alemã, tem-se a diferença de 85 anos. Quando os japoneses aportaram aqui, os imigrantes alemães e italianos já estavam edificando suas bases étnicas dentro do Brasil. 
O período entre os séculos XIX e XX foi o de grande mobilidade populacional a nível mundial. Estima-se o crescimento populacional do início do século XX em cerca de 3\% anual, o que é significativo do ponto de vista da história da humanidade.

Calcula-se que a população da Europa no início do século XIX era por volta de 200 milhões, mas nos meados do mesmo século, a emigração para a América do Norte e do Sul atingiu 40 milhões, alcançando os 70 milhões em 1940. A Europa, no período de isolacionismo e controle populacional do Japão, teve um aumento populacional correspondente ao da atual Ásia e África, tendo sido então um ponto de partida dos emigrantes. Seguindo a Europa, começam as emigrações da Índia, China, países árabes e Japão. O Japão faz parte do grupo tardio dentro dos países emigrantistas de então.

Reportando-me, agora, à origem do presidente Kennedy, que tem uma relação com batatas, dizem que na Irlanda, em 1845, devido à praga de batatas, dos 8,3 milhões de habitantes, um milhão morreu de fome. Por causa disso, após 1851, mais de 4 milhões de irlandeses emigraram aos Estados Unidos. Dentre eles, estavam os avôs do expresidente Kennedy. A batata tinha sido anteriormente levada dos Andes para a Irlanda, uma terra fria e árida, resultando num surpreendente crescimento populacional que atingiu os 8,3 milhões. Mas, após colheitas sucessivas, a plantação foi atacada por uma doença que atingiu os tubérculos, causando a morte de muitas pessoas.

Se as batatas não tivessem sido levadas da América do Sul à Irlanda, não teria acontecido o aumento da população, e ainda, se a praga de batata não tivesse se alastrado, os antepassados do Kennedy não teriam emigrado aos Estados Unidos e, por conseguinte, não teria surgido o próprio presidente Kennedy.

Aproveitando a referência à imigração nos Estados Unidos, cito um episódio relacionado ao Oregon Trail (Trilha de Oregon). Em 1993, fui enviado à Universidade do Estado de Oregon e vivi numa cidade universitária chamada Corvalis. A cidade estava animada com a festa dos 150 anos do Oregon Trail. Há 150 anos, a carruagem dos imigrantes partiam do Estado de Missouri para Oregon, a 2.000 milhas de distância em direção à Costa Oeste do país. O ponto de partida dos imigrantes era Saint Louis, à beira do Mississippi. No lugar onde se indica o começo da região Oeste, há um arco gigante com o formato do casco de cavalo. Oregon Trail era também chamado de Estrada do Cemitério porque os mortos de doença ou de fome eram enterrados ao longo de sua estrada.

Os filmes americanos do meu tempo de ginásio eram os filmes de faroeste. Ainda estão vivas na minha memória as cenas finais e emocionantes do filme Shane. Mas esses filmes, produzidos pelos brancos, eram na verdade filmes dos novos imigrantes que iam expulsando os habitantes nativos para a atual Zona de Preservação dos Índios. Esses imigrantes eram sem dúvida invasores e, devido a essas críticas, os chamados filmes de faroeste passaram a desaparecer. Apesar de serem histórias dos desbravadores, também são filmes dos imigrantes, do ponto de vista dos brancos. Entre os trabalhadores das minas e das construções de ferrovia, aparecem os chineses, os imigrantes asiáticos que dão início ao dekassegui. Ultimamente, o nome indians tende a ser substituído por "americanos nativos", no sentido de que eram americanos residentes antes da chegada dos imigrantes europeus.

Nos Estados Unidos, Colombo foi destituído da posição de um descobridor corajoso para a de um ambicioso aventureiro com más intenções. Em 1991, fui enviado 
à Universidade do Estado de Montana, em cuja capital celebrava a festa comunitária dos americanos nativos e outros, chamada "Baw Baw", ocasião em que com eles dancei no campus da Universidade. A imagem dessa festa, inicialmente associada aos desbravadores altivos montados na carruagem, mudou para à dos novos imigrantes e, atualmente, seu tema é a convivência entre os americanos nativos e os imigrantes novos. No século XIX, enquanto o Japão se encontrava isolado, os Estados Unidos formavam um Estado de imigrantes com os povos vindos da Europa.

E os dekassegui dos tempos atuais, são imigrantes ou não? Eu fiquei impressionado quando, após a queda do Muro de Berlim, vi camelôs chineses na avenida Unter der Lingen. Em 1988, antes da queda, estive em Berlim que se encontrava dividida por um muro. Eu entrei de carro por Düsseldorf para passar da antiga Alemanha Oriental para a Alemanha Ocidental, e fui rigorosamente vistoriado por cerca de uma hora no posto de alfândega mundialmente conhecido pelo nome Check Point Charly. Dois anos depois, ao revisitar Berlim, o posto de alfândega não existia mais. E o que me chamou logo a atenção foi a presença dos camelôs chineses entre os outros camelôs poloneses. Eles vinham da distante China com sua bagagem, pela Ferrovia Trans-siberiana.

Surpreendi-me por essa energia. E lembrei-me vivamente de um diplomata francês que contou, com seu humor tipicamente francês, referindo-se a Genghis Khan: "A França não tem medo da Rússia nem da Alemanha. Ela tem é medo da China. Pois da China, é possível vir a Paris de bicicleta e mesmo a pé"

Dessa forma, após a queda do muro de Berlim e o fim da guerra fria, cresceu bastante a mobilidade populacional. Em Los Angeles, encontrei casualmente um nativo de Moldávia - um dos países da antiga União Soviética - que trabalhava como motorista de táxi após a obtenção do green card e cuja filha freqüentava uma universidade americana. Perguntei-lhe por que seu inglês era péssimo e fiquei sabendo que havia chegado recentemente de Moldávia.

A maioria dos motoristas de táxi em Nova York é composta de imigrantes estrangeiros. No filme intitulado Planet, aparece um motorista de táxi que não entende bem o inglês. Ele não entende bem o destino e o passageiro, impaciente, diz: "Não se preocupe que vou pagar... mas deixe-me dirigir". É uma bela anedota.

Retornando ao tema, passo a falar da filosofia da emigração que, a meu ver, passou de emigração para a vida toda para a emigração numa só etapa da vida. Por exemplo, muitas pessoas da Inglaterra, um lugar frio, migram para a Austrália para passar a sua velhice. Nos Estados Unidos, onde passei um tempo, vivi em Montana, um estado frio perto da divisa com o Canadá, onde muitas pessoas passam a sua velhice em Phoenix, no Estado de Arizona, de clima muito mais ameno. Há também aqueles que passam só o inverno na região sul chamada Sun Belt ("cinturão do sol").

Da mesma maneira, os imigrantes de hoje já não têm a intenção de se fixar a vida toda num lugar. Em vez disso, eles almejam uma realização pessoal, considerando a passagem por um lugar apenas uma fase pela qual se optou em sua vida. Em outras palavras, são pessoas que fazem a opção de imigrante enquanto uma forma de vida numa etapa de sua realização própria. Podemos chamá-los, então, de "imigrantes de realização própria". Eles têm por característica não levar a vida tão a sério. É como aderir à moda que vai mudando. Os imigrantes inseridos em programas governamentais 
reduziram-se drasticamente mas, se incluirmos os estudantes bolsistas e não bolsistas, seu número atual hoje é muito maior do que o dos imigrantes no sentido tradicional.

Durante as pesquisas sobre os descendentes dos japoneses em Assaí, Paraná, fiquei comovido ouvindo um idoso que me perguntou: "Professor, sabe qual é a paisagem do Japão que se vê por último quando parte o navio dos emigrantes?" Eu fiquei pensando: "Não deve ser a torre de Tóquio", quando ele disse: "É o Monte Fuji. O Monte Fuji vai, no fim, afundando na linha do oceano. E nesse momento, todos nós choramos" $\mathrm{O}$ idoso, que nunca realizara o seu sonho de retornar ao Japão, chorava ao lembrar o Monte Fuji que avistou por último. Eu mesmo não consegui conter as lágrimas.

Entre os dekassegui da atualidade, naturalmente não há ninguém com esses sentimentos. O que possibilitou essa mudança foi a tecnologia. O deslocamento rápido, em massa e de menor custo através do avião Jumbo, o fax, a internet: a transmissão de informações cobre todo o mundo. Tornaram-se mais importantes a distância de tempo e a diferença de preço do que a própria distância física. Tóquio e São Paulo se situam em extremos opostos da Terra, sendo os países mais distantes do ponto de vista geográfico e físico. Dizem que antigamente a passagem de avião entre o percurso Brasil e o Japão custava mais de 1 milhão de ienes mas, agora, o preço diminuiu e a passagem de ida $\mathrm{e}$ volta mais barata custa cerca de 130 mil ienes.

O tempo de percurso também diminuiu. Se antes levava-se de 40 dias a 2 meses de navio, é uma revolução poder percorrer a distância em 24 horas de avião. A mudança do Kasatomaru para o Jumbo alterou, na base, a filosofia dos imigrantes. Agora, é possível viajar facilmente como quem diz "Vou dar um pulinho (no Japão) e já volto" No Japão, há 30 anos, havia um trem coletivo de trabalhadores migrantes. $O$ cantor Mori Shin'ichi viajou nesse trem de Kagoshima a Tóquio, levando mais de 30 horas. Era muito mais que o atual tempo necessário para fazer São Paulo-Tóquio.

O que nos dá a impressão de ter aumentado entre o Brasil e o Japão não é o tempo de percurso ou o custo da passagem mas sim a distância social e cultural. Há muitas pessoas sentindo que o Japão, a antiga pátria, está mais distante. Um imigrante me perguntou: "Há muitas palavras escritas em katakana, e o japonês dos colegiais é incompreensível, o que significa choberiba, professor?" Alguém daqui sabe o que é choberiba? É um vocábulo composto de prefixo japonês chô ("muito") e beriba, corruptela do inglês very bad, que significa no seu conjunto "muito muito mal"

No Japão, há firmas que conseguem obter para os jovens o green card, a carteira de visto permanente nos Estados Unidos. Como é possível obter os green card através de sorteios, a firma se encarrega de participar desses sorteios nos EUA. Assim, já é comum ver um jovem sushi-man do bairro de Ginza, em Tóquio, estar trabalhando num restaurante de sushi em Union Square de San Francisco.

Por outro lado, em Sidney, vemos muitos jovens japoneses visitando a Austrália em suas férias de trabalho. Como podemos analisar tais tendências?

Antes, a emigração fazia parte da política governamental e ela acontecia mediante acordo entre os governos dos países emigrantista e imigrantista. Mas hoje a decisão se baseia na opção que se faz individualmente com relação à sua vida em particular.

A individualização da emigração pode ser definida como a desoficialização ou a privatização da emigração. Calculam-se esses emigrantes em torno de 20 a 30 mil por 
ano, número esse que ultrapassa e muito o número de emigrantes oficialmente enviados pelo Japão.

Antes, o governo japonês se encarregava de esclarecer e de dar aulas de conhecimentos gerais sobre o local de destino, em centros criados para este fim, em Kobe e Yokohama mas, hoje, os seminários em universidades têm desempenhado esse papel. Eu mesmo já fui consultado várias vezes nesses seminários pelos estudantes interessados em sair do país.

Esses emigrantes que vivem além das fronteiras de seus países estão se tornando cada vez mais cosmopolitas. Ou seja, o conceito de fronteiras está cada vez mais diluído. Mas, mesmo com as fronteiras desaparecendo, o culturalismo regional e o etnicismo têm-se acentuado. Apesar do estágio avançado em que se encontra a formação da União Européia, as atividades terroristas que reivindicam, por exemplo, a independência da Irlanda do Norte não cessam. Os movimentos pela independência da Catalunha e da Escócia continuam - ou seja, o culturalismo regional parece se acentuar como uma reação à globalização dos Estados.

É sabido que, mesmo desaparecendo as fronteiras criadas artificialmente, os limites entre os grupos étnicos e culturais não desaparecem. As pessoas se locomovem facilmente transpondo as fronteiras geográficas mas sempre dentro de um universo étnico ou cultural, carregando traços de etnia, de língua, de religião. Nesse sentido, Kasatomaru pode ser chamado de veículo da cultura e da etnia ou a Arca de Noé. Os nipo-brasileiros que se deslocam com o Jumbo, versão atual do Kasatomaru, estão construindo, em via inversa, o bairro da Liberdade no Japão. A cidade de Ôizumi da província de Gunma é denominada Cidade Brasileira do Japão. Os descendentes daqueles japoneses que construíram o bairro japonês no Brasil estão construindo, agora, o bairro brasileiro no Japão. Isso demonstra que, por mais individualizada que tenha se tornado a emigração, é somente junto com o veículo da cultura que é a língua, o povo, a religião, a cultura alimentar etc. que as pessoas podem se locomover. É por isso que poucos se mudam sozinhos. As pessoas se mudam, partilhando de uma mesma identidade cultural e étnica e formam uma rede de relações e de informações para se ajudarem mutuamente. $O$ veículo da etnia e da cultura continua a sua viagem, adaptando-se à sociedade hóspede.

O dekassegui é concebido como um fenômeno recente no Brasil, mas o seu marco está nas Olimpíadas de Tóquio, em 1964 (ano 39 de Showa). Houve uma inversão do fluxo migratório por causa das gigantescas obras executadas no Japão em função dos Jogos Olímpicos, tais como a do trem-bala, das vias expressas de Tóquio, sede dos Jogos.

O Japão, um país eminentemente emigrantista até antes da Olimpíada, passa a receber de volta os emigrantes às vésperas das Olimpíadas. O início do fenômeno de volta das primeiras gerações de Okinawa para trabalhar nas obras de construção civil das Olimpíadas marca a primeira fase de dekassegui.

Com o acordo de Plaza, em 1985, quando o iene passa a se valorizar, aumenta repentinamente o número de pessoas que vão ao Japão. Essa é a segunda fase. Sabe-se que nesse mesmo ano de 1985 o número dos dekassegui sobe a 13.000 pessoas. Aparecem os anúncios de dekassegui nos jornais japoneses do Brasil.

A terceira fase começa com o início das intermediações de dekassegui, a partir de 1987. As agências de recrutamento, com fachada de agências de turismo, conseguiam 
as passagens e o emprego, enviando muitas pessoas ao Japão. Mas, foi na quarta fase que o número dos dekassegui nipo-brasileiros indo ao Japão cresce vertiginosamente. Isso se deve à nova lei de imigração que passou a conceder o visto permanente aos nisseis e sanseis e suas respectivas famílias, através do decreto-lei do Ministro da Justiça, em vigor a partir de $1^{\circledR}$ de junho de 1990 (ano 2 do período Heisei). Esperava-se, dessa maneira, que esses descendentes de japoneses passassem a substituir os trabalhadores ilegais oriundos de países asiáticos. Foi o grande vértice da mudança das medidas oficiais. Nesse período, travavam calorosas discussões pró e contra a abertura, onde tomou corpo a medida, inesperada para todos, pelos descendentes de japoneses.

Enquanto se examinavam no Parlamento as novas leis de imigração, que incluíam medidas punitivas referentes aos trabalhos ilegais, foi sancionada a concessão do visto permanente aos descendentes de japoneses, em forma de decreto-lei do ministro da Justiça, ou seja, somente com a aprovação do gabinete, sem passar pelo Parlamento.

Assim, longe das discussões acaloradas no Parlamento sobre a aceitação ou não de trabalhadores estrangeiros, foi levada adiante a medida pelos descendentes de japoneses. A reunião do gabinete que aprovou o decreto-lei na verdade foi previamente acertada na reunião com o vice-ministro, da semana anterior. Na realidade, pois, o visto permanente aos descendentes de japoneses foi decidida nesta reunião.

Após o simpósio do Centro de Informação e Apoio ao Trabalhador no Exterior (CIATE), recentemente realizada em São Paulo, conversei com a sra. Noriko Yamamoto, chefe da seção de Trabalhadores Estrangeiros do Ministério do Trabalho, e ela me perguntou enquanto comíamos feijoada: "Como é, professor, foi boa a medida de termos trocado os trabalhadores asiáticos por descendentes de japoneses?" Ao que eu respondi: "Foi boa, porque se naquele momento tivéssemos aceito legalmente inúmeros trabalhadores asiáticos, agora, com a recessão prolongada, o nível de desemprego estaria alto. $\mathrm{Na}$ época, eu realizava pesquisas a pedido do Ministério do Comércio e da Indústria e tinha sugerido que a aceitação dos trabalhadores asiáticos fosse restrita aos estagiários"

Enquanto muitos economistas discutiam, divididos entre pró e contra a aceitação legal dos trabalhadores estrangeiros no país, foram cuidadosamente feitos os acertos entre os representantes do governo, da política e do empresariado, decidindo-se pela concessão do visto permanente aos descendentes de japoneses apenas com a aprovação do Gabinete, sem passar pelo Parlamento. Foram negociações de bastidores desconhecidas pela maioria das pessoas.

Nas pequenas e médias cidades industriais, chamadas de pólos industriais de grandes empresas, como Ôizumi, da província de Gunma, Hamamatsu, da província de Shizuoka, e Toyota, da província de Aichi, os nipo-brasileiros constituem a maioria dos trabalhadores estrangeiros. Em Ôizumi, a população estrangeira registrada chegou a mais de $12 \%$ da população total, a mais numerosa do Japão. Dentre esses, $80 \%$ são nipo-brasileiros. É por isso que a cidade é chamada de Brazil Town ou o Bairro da Liberdade japonês. Os nipo-brasileiros registrados em Hamamatsu são mais de 7 mil pessoas, a mais numerosa dentre as cidades e vilas. Juntando as províncias de Shizuoka e de Aichi, que são vizinhas, o número de nipo-brasileiros ultrapassa os 60.000 , formando uma grande comunidade. Surgiu assim uma colônia de nipo-brasileiros no Japão, maior do que a do Brasil. 
Nessas cidades, há lojas de varejo de diferentes tipos, restaurantes, discotecas, salões de beleza, locadoras de vídeo ao estilo brasileiro, que permitem um estilo de vida igual ao do Brasil.

Quando as condições de aceitação no Japão são satisfatórias, surge uma camada de pessoas que desejam fixar residência no país. Há quem tenha até comprado casa própria. Em outras palavras, criou-se uma situação em que não é mais adequada a terminologia dekassegui, ou seja, "aquele que sai temporariamente do país de origem para ganhar dinheiro"

Dizem que o capital estrangeiro enviado pelos nipo-brasileiros ultrapassa os 2 bilhões de dólares por ano. Segundo informação mais recente, esse valor teve uma diminuição de $15 \%$. Por outro lado, há ainda quem afirme ser 3,6 bilhões ou mesmo 4,6 bilhões de dólares. Como ainda há muitos que trazem o dinheiro escondido, informalmente, o valor deve ser ainda maior. $O$ valor oficialmente estimado corresponde a 5\% do valor total da exportação brasileira. Os dekassegui tornaram-se uma figura indispensável para a economia brasileira, estabelecendo uma nova ponte inquebrantável entre os dois países.

A exportação do Brasil ao Japão em 1996 foi 3,1 bilhões de dólares. Se considerarmos que a remessa dos dekassegui é, em outras palavras, a renda líquida que provém da exportação da força de trabalho, podemos compreender o quão grande é esse valor. $\mathrm{O}$ mesmo podemos dizer quando comparado com o investimento japonês no Brasil, estimado em 350 milhões.

Por outro lado, diz-se que o fenômeno dekassegui está esvaziando a comunidade nipo-brasileira e para apreender a situação real, realizei uma pesquisa em Assaí e Bastos, "cidades japonesas" construídas pelos imigrantes e consideradas como as que mais preservam as características japonesas. Enfoquei nessa pesquisa o papel do dekassegui enquanto fator motriz de vitalização e esvaziamento da comunidade.

Em primeiro lugar, destaca-se a opinião de que o fenômeno dekassegui "contribuiu para a continuidade da língua e cultura japonesas", tanto em Assaí quanto em Bastos. Não são poucas as oportunidades de se estudar no Japão, como por exemplo, através de bolsas de estudo do Ministério de Educação e das províncias, bolsas de estágio etc., mas o número dos que tiveram a experiência de contato com a língua e cultura através de dekassegui é incomparavelmente maior, o que justifica essa avaliação.

"O fenômeno dekassegui contribuiu para a vitalização da comunidade nipobrasileira no Brasil?" A essa pergunta, 73\% em Bastos e 72\% em Assaí responderam positivamente, incluindo o "sim, muito" e "sim, relativamente bastante"

Dentro dessa vitalização, incluem-se a "construção de casa nova ou reforma de casa, aquisição de bens de consumo duráveis", o "contato com a sociedade japonesa", o "acúmulo de capital para negócios, liquidação de dívidas, poupança para a educação dos filhos" e o "aumento do intercâmbio com o Japão"

Apesar da existência de uma tendência de esvaziamento, a história segue seu rumo num processo ainda maior de vitalização. Não é possível mudar o rumo da história. Podemos assim interpretar que uma nova história das relações entre o Brasil e o Japão está sendo construída numa velocidade inimaginável. 
Em 1995, quando fiz uma pesquisa com os pais de uma escola alemã privada, da classe média alta na cidade de São Paulo e também com os alunos dos cursos de Italiano e Alemão da USP, o que mais me chamou a atenção foi a preferência étnica do parceiro para se casar. Na escola particular, os pais responderam pelos filhos e, na faculdade, os próprios estudantes, mas em ambos a preferência era pelos "descendentes de alemães ou italianos" ou então "de origem européia" Eram poucos os que desejavam se casar com os descendentes dos japoneses. Pude sentir, então, o alto grau de consciência étnica dos descendentes de alemães e italianos das classes média e alta.

Será que os imigrantes japoneses, já com 90 anos de história, irão se aculturar cada vez mais, perdendo sua língua e cultura?

O alto grau de consciência étnica dos descendentes de italianos, com 125 anos de imigração, e de alemães, com 175 anos de imigração, que juntos constituem, entre os imigrantes, a maioria das classes média e alta da sociedade brasileira, é suficiente para nos fazer sentir o peso de sua história. $O$ resultado dessa pesquisa nos mostra que, mesmo com o avanço do processo de aculturação, ainda está forte a consciência cultural e étnica desses imigrantes europeus de classe média e alta.

Mesmo que as fronteiras desapareçam, a identidade étnica e cultural está em alta. Dessa maneira, a integração entre povos e culturas do Brasil, um país de imigrantes, se faz sustentada na construção das personalidades étnicas e culturais próprias de cada grupo. A sociedade nipo-brasileira, pois, deve também estimular a formação de uma rica personalidade. Espero que o fenômeno dekassegui contribua para essa formação étnica e cultural da comunidade nipo-brasileira.

A colônia japonesa teve seu início como um grupo coletivo de produção. Em seguida, foram formadas entidades como Bunkyô (associação cultural), Enkyô (associação beneficente) e Kenjinkai (associação de imigrantes por província). Diz-se que essas entidades estão em perigo de sobrevivência devido ao dekassegui, mas devese considerar que há uma remessa considerável de capital estrangeiro vindo do Japão graças a eles e que mais de $70 \%$ de pessoas estão satisfeitas com os dekassegui.

Nesse sentido, para se atingir o desenvolvimento no século XXI, é imprescindível que a colônia japonesa considere positivamente o fenômeno dekassegui, do ponto de vista de sua vitalização, e que reintegre não somente os descendentes residentes no Brasil mas também os residentes no Japão, com vistas a uma união global dos nipobrasileiros, transpondo as fronteiras entre o Brasil e o Japão. Eu me refiro, por exemplo, ao projeto de construção do Instituto Nipo-Brasileiro no Japão, sob a iniciativa do Bunkyô e a criação da Seção de Atendimento aos Dekassegui, por iniciativa do Enkyô.

O fenômeno dekassegui é a "japonização" da comunidade nipo-brasileira no sentido de nela introduzir o novo Japão, o que significa a globalização. Gostaria que essa comunidade tenha um novo desenvolvimento dentro dos processos de japonização e de globalização.

Por outro lado, os dekassegui brasileiros difundiram a cultura brasileira por todo o Japão. Eles estão fazendo do Brasil uma presença mais próxima para os japoneses. $O$ Japão vai participar pela primeira vez da Copa do Mundo, onde foi grande a contribuição dos brasileiros. No Japão paira um ar de recessão, mas espero que a cultura brasileira contribua para dar um tom mais alegre e caloroso à cultura japonesa, que tem um aspecto 
um tanto sombrio e frio. É importante que o processo de "abrasilianização", no bom sentido, ocorra no Japão através dos dekassegui.

Por fim, finalizo a minha palestra, expressando a minha esperança de que, através do dekassegui, o relacionamento entre o Brasil e o Japão se estreite cada vez mais, em prol do desenvolvimento de ambos os países. Obrigado pela atenção.

(Tradução Junko Ota) 